\title{
COALITIONS MODEL IN INDONESIAN PRESIDENTIAL SYSTEM
}

\author{
Dinoroy Margonda Aritonang* \\ Bagian Ilmu Hukum, Sekolah Tinggi Ilmu Administrasi Negara, Bandung \\ Perwakilan Bandung \\ Jalan Cimandiri, 34-38 Bandung 40115
}

\section{Abstract}

The option to pick a suitable governmental system is greatly determined by political stability and effectivity considerations. Presidential system used in Indonesian constitutional system is designed along with the format of multiparty which highly requires coalitions among political parties in the parliament. This feature is actually an original or a real character of parliamentary system. It stems from and is developed well in the system. In this article, it will be described the problems based on empirical experiences of Indonesian Presidential cabinet which is struggling with the multiparty system.

Keywords: Coalitions, Presidential, Multiparty.

\section{Intisari}

Pemilihan model pemerintahan amat ditentukan oleh pertimbangan terhadap stabilitas dan efektifitas dari pemerintahan. Sistem Presidensil yang diterapkan di Indonesia didesain dengan format multiapartai, yang amat menghendaki koalisi dalam partai politik di parlemen. Ciri ini sebenarnya amat cocok (lahir dan tumbuh subur) dalam sistem parlementer. Dalam tulisan ini dideskripsikan mengenai problematika yang berangkat dari pengalaman empiris cabinet pemerintahan yang telah berlangsung di Indonesia dalam desain presidensil yang multipartai.

Kata Kunci: koalisi, presidensil, multipartai.

\section{Pokok Muatan}

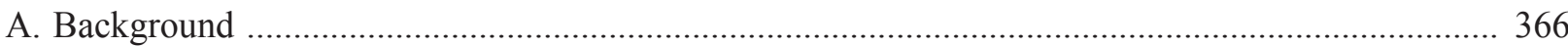



1. Indonesian Presidential System After the Amandments of Constitution .................................... 367

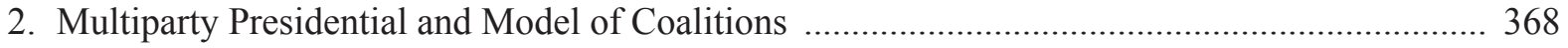

3. Coalition-Building Experiences in Indonesian Presidential System ........................................ 372

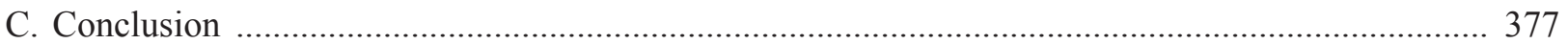




\section{A. Background}

The dynamics of governmental management in Indonesia have continually changed and developed along with the political dynamics for the past decades. The condition has been certainly influenced by many political, legal, and social factors existed in Indonesian constitutional and political system after the amendments of the 1945 Constitution of the Republic of Indonesia.

Related to political cases in Indonesia, a stable and effective governmental management process has become a very important element in order to make many relevant policies and programs, especially, when the policy and program are closely related to the development issues.

The opportunity to choose a governmental system among a variety of designs and examples in the world is higly related to the motives to reach political stability and effectivity of the governmental management process itself. Moreover, there are also many factors influencing the management such as political system and practices, recruitment model of political and public officers, the power configurations between local and national government, and the configurations of political and institutional relations between executive branch and legislative assembly.

In presidential or parliamentary system, ${ }^{1}$ political and governmental stability are the main stakes for the regime. In parliamentarism model, the stability instrument is characterized by the fusion of executive and legislative power, achieved by the mechanism that the government needs the vote of confidence from the majority in the legislative assembly in order to get and maintain the power. ${ }^{2}$ On the contrary, presidentialism model applies the separation of power and function between the president and parliament as the axis for the governmetal stability so there is no room for both branches to dissolve mutually. Further, the fixedterm of office for the president has strengthened the characteristic of the design. ${ }^{3}$

The forms and models of political coalitions in Indonesia have dynamically developed and changed along with the political and democratic practices. The conditions are influenced by the form of political relations and interests among the actors in executive and legislative branch. For the further extent, it has been much affecting political parties to build the form and pattern of political relations in supporting the cabinet.

Empirically, in Indonesian political experiences, coalition is something which can not be avoided. It is affected by many factors, i.e: the multiparty system itself, a juvenile term of presidential democracy which has been just maintained for almost fourteen years since the last amendment of the 1945 Constitution of the Republic of Indonesia (in another word, Indonesian democracy is still looking for a political balance), a variety of policy preferences and interests from each political party in Parliament, and last but not least, the desire of the parties to reach and maintain the powers in government or to be around the circle of power in the context of enlarging their influence and existence.

Related to the problems, this article is basically made to describe and to analyze - through qualitative and theoretical approach - the model or form of political coalitions and relations which have been dynamically going on in Indonesian

\footnotetext{
Any variation in governmental system and the modifications of the model, out of the two popular mainstreams, will consider stability of the cabinet as one of the important dimensions.

Jose A. Cheibub, "Systems of Government: Parliamentarism and Presidentialism", http://www.hks.harvard.edu/fs/pnorris/Acrobat/stm103\%20 articles/Cheibub Pres Parlt.pdf accessed on 12 January 2016.

Research by Scott Mainwaring and Juan J. Linz had stated different results and conclusions that several features of presidential systems contribute to explaining why so few have become stable democracies are the possibility of prone to immobilism, weak executive power, and destabilizing executive/legislative conflict than parliamentary systems. See Scott Mainwaring, "Presidentialism, Multiparty Systems, and Democracy: The Difficult Equation", Working Paper \#14, Kellogg Institute, September 1990, pp. 9. Further, Linz added that parliamentary democracy is more stable than the presidential. That's because the concept of parliamentarism provides a more flexible and adaptable institutional context for the establishment and consolidation of democracy. The fusion between the cabinet formation and the coalition in parliament would foster responsible decision making and would encourage genuine party competition without causing undue political fragmentation. See Juan J. Linz, “The Perils of Presidentialism”, Journal of Democracy, Vol. 1, No. 1, 1990, pp. 51-69.
} 
presidential system after the amendments of the 1945 Constitution of the Republic of Indonesia.

\section{B. Research Results}

\section{Indonesian Presidential System After the} Amandments of Constitution

According to Bagir Manan, Indonesian presidential system, before the amendments of the 1945 Constitution had some resemblances with the American presidential system, with several special characters. ${ }^{4}$ Although it might be right, many scholars argues that Indonesian governmental model before the amendments was not a pure presidential. That's because the system was combined with some parliamentary features. One of designs was the responsibility obligation mechanism of President to the Indonesian People Assembly (MPR) which was notably believed as one of the form of parliamentary institutions. Moreover, there were roles of the assembly to assign the president by giving him/her a constitutional mandate or to terminate the term of office through a political reason. ${ }^{5}$

It is really different when we see the Indonesian presidential model after the amendments period. One of the prominent features of the presidentialism designed in the amended Indonesian constitution is Article 7C which regulates that the President has no power to freeze and/or dissolve the House of Representatives. ${ }^{6}$

The other features from the amendments of constitutions indicating the application of pure presidential system in Indonesia are as follows:

a. The use of 'President' terminology as a description to presidential roles as a head of government and a head of state. The separation of both roles is one of the features of parliamentary model.

b. The principle of separation of powers, according to Article 1 verse (2), denotes that no single branch is more supreme than the others.

c. The application of President and VicePresident direct election, according to Article 6A which is separated with the direct election for legislative members. So, there is no fusion between the composition of political parties in parliament and the election of the President.

d. Legislation role has been given back to parliament (DPR), according to Article 5 verse (1), and the President is only one of the inisiator.

e. The promotion and dismissal of a Minister is a prerogative power of the President without any consideration or consent required from the parliament (DPR), according to Article 17 verse (2).

f. 5 (five) years fixed-term of office for President and Vice-President according to Article 7.7

g. According to the constitution, President is no longer responsible to any political institution but to the people. This principle is as a legal and political consequence of the implementation of direct election for President and VicePresident. ${ }^{8}$

From the constitutional provisions above, we can conclude that the governmental model used in Indonesian constitutional system after the amendments is no-longer a semi-presidentialsm but a pure presidential system.

The problem is that pure presidential system is not designed like the American presidentialsm with only two strong and established political parties.

\footnotetext{
Bagir Manan, 1999, Lembaga Kepresidenan, Gama Media, Yogyakarta, pp. 59.

Furthermore, the amendments have also changed other political institutions functionally and institutionally. These adjustments have already made Indonesian governmental system purer than before the amendments of the constitution. See Jimly Asshiddiqie, 2005, Implikasi Perubahan UUD 1945 Terhadap Pembangunan Hukum Nasional, MKRI, Jakarta, pp. 37.

Historically, some political experts hold that the article was a respond to former Indonesian President Abdurrahman Wahid (Gus Dur) who ever issued a Decree to dissolve the parliament. But, in a conceptual perspective, some others also argued that the existence of the article is a natural thing because we picked presidentialsm and separation of power as the mainstreams in the constitution. Impeachment process is also designed in Article 7A of Indonesian constitution.

In practice, there is a political convention for the President to convey an annual performance report of the cabinet in parliament, but this can not be justified as form of responsibility mechanism to Parliament like a Prime Minister does in parliamentary system.
} 
Unfortunately, Indonesian presidential model is combined with multiparty system which opens many political parties to participate in government and parliament through direct election. Moreover, the amendment of Indonesian constitution has given bigger and stronger power for Indonesian parliament in overseeing the President and the cabinet. Thus, it makes the Parliament looks more supreme than the President.

\section{Multiparty Presidential and Model of Coalitions}

Presidential system was created as a democratic alternative or comparison to the parliamentary government. The option to use a certain governmental model and to combine it with another feature is entirely a political question. Ideally, the option to decide a suitable form of party system is related to many relevant factors, such as multi-ethnic groups or society, historical dimensions, or effective and stable government. As Linz suggests that every country has unique aspects that one must take into account. ${ }^{9}$

Multiparty system consists of more than two dominant political parties. The system is believed as a product of a complex or multi-cultural society. ${ }^{10}$ Multiparty system is very compatible when it is applied in a plural nation like Indonesia. As lijphart ${ }^{11}$ states that in plural societies, with sharp cultural, ethnic, religious, or linguistic cleavages, multiparty systems could be more propitious in promoting stable democracy.

Related to the governmental system, multiparty is considered to be more compatible when it is combined with the parliamentary system. Because in parliamentary model, the cabinet (led by the Prime Minister) is born and shaped from the political consensus among dominant parties in parliament which intend to build a stable government or cabinet. Although, there is a room for the parliament to dissolve the Prime Minister and the cabinet (and also for the PM to do the same thing), but in the name of the stability, there will be so much political and consensual effort and interest to maintain and to keep the cabinet as long as possible. ${ }^{12}$

In a multi-party parliamentary system, coalition of political parties to dominate the cabinet and parliament is an absolute option. It is a logical consequence in order to assure the cabinets enjoy a stable and effective political environment to promote policies and programs. As Lijphart mentioned that in parliamentary systems of government, cabinets have to be formed so that they will enjoy the confidence of-or will at least be tolerated by a parliamentary majority. ${ }^{13}$

The condition is totally different with the presidential system of government. Instead of taking the fusion of the two branches, presidential system (as mentioned before) predicates its stability feature by separating the cabinet and the parliament. ${ }^{14}$ As the consequences, frictions and strained relations between the president and parliament become more potential in presidential system. This condition could possibly occur for a long period of time unless the president and cabinet resign from the office or political consensus between the parties taken into account.

Coalitions in presidential system could happen when the cabinet or government is trapped in a divided condition. Divided government refers just to presidential systems in which no single party controls both the assembly and the presidency.

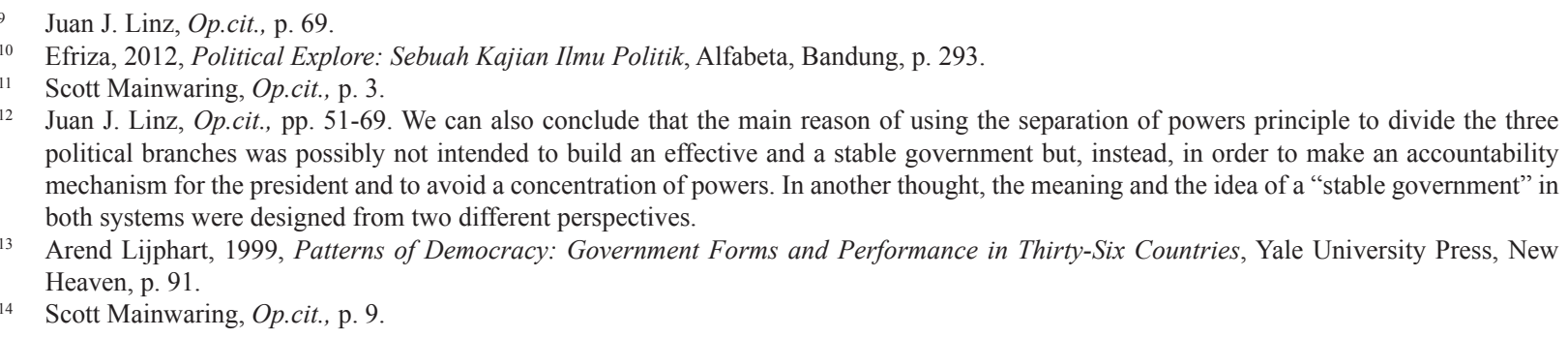


Divided government thus arises not just when the assembly and the presidency are in different partisan hands. $^{15}$

Literally, coalitions can be considered as a unification. Coalitions are groups of individuals who deliberately and independently interact and structure the joint institution outside formal organizations. This type of coaliton is usually perceived as a mutual-benefit relation among the internal members, problems and critical issues oriented-group, and it needs mutual actions from each member of the coalitions. ${ }^{16}$

In accordance with Lijphart's argumentations, ${ }^{17}$ a coalition model can be built or predicted through 6 (six) coalition theories, i.e.: First, Minimal Winning Coalitions. By using the "size-principle" of William H. Riker's theory, this model predicts that minimal winning coalitions will be formed through winning (majority) coalitions in which only those parties participate that are minimally necessary to give the cabinets majority status. One of the factors which force the parties to collaborate is that political parties are interested in maximizing their power through holding as many of the cabinet positions as possible.

Second, Minimum Size Coalitions. By quoting Lijphart's idea, if political parties want to exclude unnecessary partners from a coalition to maximize their share of cabinet power, they should also be expected to prefer the cabinet to be based on the narrowest possible parliamentary majority.

Third, Coalitions with the Smallest Number of Parties. This theory is based on the concept of "bargaining proposition" proposed by Michael Leiverson. This theory argues that minimal winning coalitions will tend to involve the smallest possible number of parties, because negotiations and bargaining (about the formation of a coalition) are easier to complete, and a coalition is easier to hold together, other things being equal, with fewer parties.

Fourth, Minimal Range Coalitions. This theory makes the plausible assumption that it is easier to form and maintain coalitions among parties with similar policy preferences than among parties that are far apart in this respect.

Fifth, Minimal Connected Winning Coalitions. According to the theory proposed by Robert Axelrod (1970) that coalitions will be formed by inviting "connected" party that is adjacent on the policy scale and devoid of unnecessary partners. The underlying assumption of this theory is that parties will try to coalesce with their immediate neighbors and that other adjacent parties will be added until a majority coalition is formed.

Lastly, Policy-Viable Coalitions. This theory assumes that parties truly care only about policy instead of holding office, real power resides in the legislature, where major new policies have to be enacted, rather than in the cabinet. This theory proposes the importance of "core party" which contains the median members of parliament to care about a policy.

One of the main issues in this article is what would happen with the cabinet when a multiparty system is combined with presidential system; would it be making the cabinet and democracy stable and effective. Scott mainwaring, ${ }^{18}$ through his prior research, stated that coalition building tends to be more problematic in presidential systems than in parliamentary systems because of differences in how executive power is formed and maintained.

Related to this case, Azari, Brown, and Nwokora, took examples from several cases in American presidential management process, which leads to the conclusion that leadership capacity is the essence of the presidency. But effective presidential leadership must balance the national demands against partisan pressures. This is one of the interesting parts of the leadership dilemma. ${ }^{19}$

\footnotetext{
15 Gary W. Cox and Matthew D. Mccubbins, "The Institutional Determinants of Ecoomic Policy Outcomes", http://wcfia.harvard.edu/files/ wcfia/files/671 mccubbins cox.pdf, accessed 10 Januari 2016. 
A President in multiparty system should have the ability and skill to see similarities of policy and interest preferences among the political parties in parliament and then to elaborate them to be a real political relation. Political coalition becomes more inevitable, although, in the process, there will be a clear potential for the coalitions to dissolve. ${ }^{20}$

Related to role and problems of the political parties, according to Apter, ${ }^{21}$ established parties in many countries within a multicultural society, basically, tend to break or separate and to be independent mutually. Those parties do not have a desire to make a coalition. But, when the country has more than two or many parties involved in political system, it may influences them to initiate bargaining process to make a coalition in the cabinet.

If the cabinet tends to compromise, then the compromist government will bring some consensual interests and decisions. ${ }^{22}$ Lijphart took an example of the American experience as one of the empirical data, arguing that the clearest example of executivelegislative balance in USA, typical of the consensus model of democracy, and the first characteristics of the consensus model are executive powersharing and grand coalitions. The presidency would have to be made collegial in order to facilitate the consensual requirement of power-sharing. ${ }^{23}$

In that system, one of the duties of the president and his/her supporting party is acting as a coalition builder. As a result, the challenge of uniting disparate groups with competing interests and values acquires much of its complexity because presidents build coalitions in markedly different arenas. ${ }^{24}$

Further, in order to build and maintain the harmony of the political relation in a multiparty system, president has to use all his political and nonpolitical modalities and capacity. The president's resources can be including the bargaining powers that come with the position, professional reputation, and public prestige. ${ }^{25}$

In the context of presidential system, President also serves as both defenders of national interest and the leaders of their political parties. Unfortunately, those are often incompatible roles. ${ }^{26}$ The discrepancy is caused by the different political intentions and values of both interests. Frequently, party' interest is not accordance to the national concerns. ${ }^{27}$

Pursuant to the obstacles described before, the presidential stability instrument through separation of purpose and power principle becomes more problematic and fragile. This is also one of the main drawbacks of presidential design, because it potentially causes deadlock and paralysis in policy making process. ${ }^{28}$ Based on data for all presidential democracies that existed [..], (it) shows (a) that characteristics of the electoral and party sistems do affect the level of support for the president in congress and hence the probability of minority presidents and minority governments; (b) that these characteristics, and the minority governments they

19 Julia R. Azari, et al., 2013, The Presidential Leadership Dilemma: Between the Constitution and a Political Party, Suny Press, New York, p. 5 .

20 As Julia R. Azari, Lara M. Brown and Zim G. Nwokora argue that American presidential system also, with only two biggest parties (Democrat and Republic), encounter deadlock when it comes to a minority of votes in parliament. To solve the problem, lobbies become one of the effective ways to break the deadlock. See Ibid., p. 9.

David E. Apter, 1977, Intoduction to Political Analysis, Winthrop Publishers Inc., Cambridge, p. 152.

Ibid., p. 156

Arend Lijphart, 1984, Democracies: Pattern of Majoritarian and Consensus Government in Twenty-One Countries, Yale Universtity Press, New Haven, p. 85.

24 Julia R. Azari, et al., Op.cit., p. 8-9.

25 Wiki Summary, "President's sources of power(Richard Neustadt)", http://wikisum.com/w/Neustadt: Presidential power, accessed 12 January 2016.

26 Julia R. Azari, et al., Op.cit., p. 8-9.

27 According to Apter' analysis, political parties become a single-important medium in politics, competitiveness, bargaining process, and negotiations. Political party enables its members to stand closer to the public and at the same time, becomes a different figure for some people as well. Moreover, political parties become the source of political deviations. But for another purpose, parties could also bring changing moments for public and personal opinions, factions, and competing demands to get closer to the public interests. See David E. Apter, Op.cit., pp. 151-152 and 155 .

28 Arend Lijphart, 2002, Parliamentary Versus Presidential Government, Oxford University Press, New York, p. 15. 
generate, do not make deadlock more likely; and (c) that minority presidents, minority governments, and deadlock do not affect the survival of presidential democracies. Together, these findings suggest that the view that explains the instability of presidential democracies in terms of the type of executivelegislative relations these regimes are likely to induce must be abandoned. ${ }^{29}$

In the democratization context, multiparty system can open many positive and massive opportunities for society to participate and become part of the direct election. This condition could bring democracy into condusive political environment. But empirically, as Linz ${ }^{30}$ argued, the real problem is that a presidential regime leaves much less room for tacit consensus-building, coalition-shifting, and the making of compromises which, though prudent, are hard to defend in public.

The weaknesses can be more described, at least, in several conditions, i.e.:

Firstly, presidential with multiparty system can lead to the instability of cabinet or government, because it shares an equally-strong position for both branches. Consequently, in this design, political lobbies and negotiations among the parties in parliament become more rigid and inflexible, because members of the parliament have no strong emotional-political relation to the president. As Bagehot stated that their mutual independence spells a mutual antagonism that weakens both of them. ${ }^{31}$

Secondly, to build a strong and cohesive political relation in a presidential-multiparty system, parties need to be more disciplined and consistent to support and maintain the coalition and the cabinet. This pre-requisite is more natural and logical in parliamentary system. Because Prime Minister and cabinet have to build a cohesive relation with the parties by cleverly combining their executive powers with the responsibility before the parliament. And as the consequences, it will lead to the well disciplined and strong political parties. ${ }^{32}$ To support the argument, Cheibub explained that:

[...] The majoritarian imperative that supposedly characterizes parliamentary regimes provides ineluctable incentives for political parties to cooperate with the government and for individual members of parliament to comply with party directives. As a consequence, highly-disciplined parties tend to cooperate with each other in forming legislative coalitions out of which governments will emerge and upon which they will rely for their existence. ${ }^{33}$

Thirdly, the elect-president in a presidential system is a popular figure and he/she gains direct support in public. But the popularity does not always bring support or acceptance from the majority of parties in parliament. Moreover, when the president/cabinet and the majority of parties are in different sides or in a divided position. Eventhough, the parliament can not dissolve the cabinet and overthrow the president but it will lead both institutions into deadlock situation.

Lastly, this design will force the president and his/her supporting party to collaborate and to open coalitions with other parties in parliament in many potential ways. As Cheibub stated:

Presidents who find themselves in a minority situation may enter into coalition to obtain thesupport of a majority in congress. They do so by distributing cabinet positions to parties that pledge their support to the government in congress. Government, thus, is here defined by all the parties that hold cabinet positions, and the government legislatif support by the sum of seats held by all the parties that are in the government. ${ }^{34}$

\footnotetext{
Jose Antonio Cheibub, 2002, "Minority Governments, Deadlock Situations, and the Survival of Presidential Democracies", http://cps. sagepub.com/cgi/content/abstract/35/3/284, accessed on 29 October 2009.

Juan J. Linz, Op.cit., p. 68.

Arend Lijphart, 2002, Op.cit., p. 15.

Ibid., p. 126.

Jose Antonio Cheibub, Op. cit., p. 24

Lowell also explained that coalition cabinets are short-lived compared with one party cabinet. The larger the number of discordant groups that form the majority the harder the task of pleasing them all, and more feeble and unstable the position of the cabinet. See also Arend Lijphart, 1984, Op. cit., p. 109.
} 
3. Coalition-Building Experiences in Indonesian Presidential System

In Indonesian presidential multiparty system, coalitions have been frequently happened. There are many empirical evidences to describe various political practices and problems in the coalitons. From the era of former President Susilo Bambang Yudhoyono (SBY) and former Vice-President Muh. Jusuf Kalla (JK) to the era of President Joko Widodo (Jokowi) and Vice President Muh. Jusuf Kalla (JK), there have been many political experiences from each regime beside pros and cons related to the multiparty system.

In a multiparty design as mentioned above, coalition is something which can not be avoided and denied by anybody who will become a president. It is an inevitable thing because it can bring stability and effectiveness for the president and the cabinet. ${ }^{35}$ Basically, a successful and cohesive coalition needs so many supporting elements and a condusive political environment. But from another perspective, it also depends on the capacity of the leader and member of the party to see the potential coalitions among many political interests cleverly and wisely. Lijphart ${ }^{36}$ explained that there are several reasons which can bring the failures to predict cabinet coalitions satisfactorily:

First, parties' policy preferences cannot be ignored. This means that parties are not pure power maximizers. They want to participate in cabinets not just in order to hold a share of governmental power but also to collaborate with other like-minded parties and to advance particular policies.

Second, a major problem in evaluating coalition theories is how to define the membership of coalitions. A political party is a member of a cabinet coalition if one or more of its representatives become cabinet ministers. But it also possible for a party to support a cabinet without entering it.
Third, the assumption that parties want to acquire a maximum share of cabinet power is usually interpreted as implying that they will seek to enter a cabinet whenever a new cabinet has to be formed.

Fourth, the assumption of power maximization leads to prediction that the smallest possible winning coalitions will be formed, but there may be important countervailing pressures that will tend to enlarge coalitions.

Fifth, another factor that may force the enlargement of coalitions is that "winning" does not always mean merely having a regular parliamentary majority.

And lastly, conversely, a cabinet may be "winning" with less than majority support in parliament. This can be achieved not only with the help of steady support parties, as discussed earlier, but also if a cabinet is able to find shifting parliamentary majorities to lend support on votes confidence and legislative proposals.

Empirically, by capturing the experiences of political parties in Indonesia, it can be concluded that there are some indicators to analyze what type of coalitions possibly occurred. Those indicators are size of coalitions which likely arranged with the calculation of the amount of members in parliament, policy preferences and ideology carried by the parties, record of the party discipline from its prior coalitions, cohesiveness level of the political parties, behaviors of most members in parliament in responding the cabinet' policy and the directives of the parties, and forms of coalition institutionalization.

\section{a. Coalition Building in The Era of SBY-JK and SBY-Boediono}

Coalition practices in both of eras are actually different. The differences are caused by some factors, i.e.: the composition

35 The difficulties of the combination of presidentialism and multiparty systems are compounded by the problems of coalition building in presidential systems. In a multiparty system, the chief executive's party rarely if ever enjoys a majority in the legislature. Consequently, to attain a majority, interparty coalition building is essential. In multiparty parliamentary systems, coalition building often creates the basis for a stable government. Building stable coalitions is considerably more difficult in multiparty presidential democracies. See also Scott Mainwaring, Op.cit., p. 21

36 Arend Lijphart, 1984, Op.cit., pp. 52-55. 
of supporting parties, political modalities of each President and Vice-President, form and political reason of the coalition, and party compositions in the parliament.

\section{1) The Era of SBY-JK (2005- 2009)}

In the era of SBY-JK, coalition was basically made in order to reap the majority of chairs in parliament. At that time, PDI-P, as one of the biggest party in parliament, chose to be the opponent without any intentions to enter coalition intiated by the Democratic Party (Demokrat) to support the cabinet of SBY-JK. ${ }^{37}$

This pair of candicates was initially supported by only four parties (Democrats, PBB, PKPI and PKS) with a minority of members in parliament (113 chairs or $20.5 \%)$. $^{38}$ The coalition was declared as "Kerakyatan" coalition (Koalisi Kerakyatan). Fortunately, JK' winning as the new leader of Golkar Party (Golkar) at VII-National Conference in Bali had turned the position from a balancing party to be part of the coaliton. ${ }^{39}$

Furthermore, the shifting of political position of Golkar and the victory of SBY-JK in the Presidential Election had influenced some political parties to join the coalition, such as, PAN, PBR, and Pelopor. This new collaboration made the position of coalition to be the majority. ${ }^{40}$

As mentioned above, in presidential system with multiparty design, political coalition character is not tightly bound and consistent as in parliamentary system. It can be seen from the records of the coalition members in the era of SBY-JK which had low discipline and cohesiveness. Conflicts among the political parties in coalitions and between the coalition and the cabinet were frequently happened rather than with party members outside the coalition. This condition made some members of coalitions become more opposite than PDI-P as the real opponent.

Moreover, personal competition between SBY as the President and $\mathrm{JK}$ as the Vice-President had come up during the tenure of the cabinet. This condition eventually made SBY chose to separate with $\mathrm{JK}$ in the next Presidential Election in 2009. At that time, SBY chose Mr. Boediono (former Governor of Indonesian Central Bank and a public official with no political background) as the next candidate of Vice-President. And at the same time, JK picked Mr. Wiranto as his pair of candidates.

If we analyze the type of coalitions from Lijphart's perspective as mentioned before, the coalition in this era, actually, can be concluded as one of the examples of "Minimal Winning Coalitions". It can be seen from the initial intention of the members in coalition (and also the candidates) to collect the majority of votes in parliament in order to support the program and policy of the cabinet

\footnotetext{
In frequent moments and political relations, PDI-P also declared the term "balancing party". This was also what Golkar used before joining the coalition with the Democrat.

38 In this era, parliament was dominated by two groups of coalition, "Koalisi Kerakyatan" as the supporters for SBY-JK and "Koalisi Kebangsaan" as the opponent or balancing parties initiated by PDI-P.

39 Siska Yuspitasari, "Sistem Multipartai di Era Pemerintahan Susilo Bambang Yudhoyono 2004-2009”, Jurnal Dinamika Politik, Vol. 1, No. 1, August 2012, p. 28.

$40 \quad$ Ibid., p. 29.
} 
and the elect-President and VicePresident. In addition, the distribution of ministerial positions for the coalition members showed that political parties are interested in maximizing their power through holding as many of the cabinet positions as possible.

\section{2) The Era of SBY-Boediono} (2009-2014)

In this era, many scholars viewed that the candidacy of $\mathrm{Mr}$. Boediono as the next Vice-President for SBY was a bit-forced. It is because Mr. Boediono' profile as a non-partisan and a pure public official without any experience in political relation with any party. Eventhough the coalition members had some figures who can be promoted. But, at that time, many polings were still reckoning SBY as the most popular figure for the candidacy no matter who was the candidate of the Vice-President. And this benefit made Democrat Party and SBY had a legitimacy to choose the candidate of Vice-President of its own. ${ }^{41}$

The election in 2009 brought out 9 (nine) political parties (from 38 participated in the election $)^{42}$ to enter the parliament with no single party had the majority of votes. Even the Democratic Party, as the largest gathering, had only come up with $26.4 \%$ votes or 148 chairs in parliament (from total number of 560 chairs). The result had forced SBY and Democrat and the initial supporting members to invite other parties in parliament to enter the coalition, such as, Golkar (which had been defeated in the election and had chose Aburizal Bakrie as the new leader of Golkar Party), PKS, PPP, PAN, and PKB. The new coalition finally made 423 chairs in the parliament, far above the minimal majority of votes (51\%).

The coalition model in the Era of SBY-Boediono was quite similar with previous coalition in 2005-2009. Eventhough, there were still some differences between the two periods. Learning from the past experiences, the Democratic Party had tried to build stronger and more cohesive coalition. The Party wanted each of the coalition members to be more consistent and well-diciplined to support the cabinet. One of the political approaches that the Democrat and coalition members used is by institutionalizing the coalition through a "Joint Secretariat" declaration (Sekretariat Gabungan) with a memorandum of understanding document, signed by each leader of the parties.

But, evidently, an institutional approach in political relation is not the panacea to attain a stable and cohesive coalition. The real problems stem from the design of the multiparty and presidential system itself. Conflicts between the cabinet and the coalition and among the members of the Joint Secretariat emerged frequently. And it was even more evident than the conflict between the Democrat and PDI-P. ${ }^{43}$ Moreover, sometimes, some members of the coalition built an informal political relation with the opposite party. 
If we used the theory of coalitions from Lijphart's perspective as mentioned before, the coalition in the era of SBY-Boediono, actually, can be concluded as one of the examples of "Minimal Winning Coalitions" as well. It can be argued from the initial intention of the members of coalition to collect the majority of votes in parliament in order to support the program and policy of the cabinet. Although, by declaring Joint Secretariat, there was an initial effort and intention to build the coalition on the basis of policy preferences and not only consider the majority of votes as the background, but this effort was apparently useless.

Learning from the case, Democrat and the intial members of coalition actually can consider another approach in building stronger and more cohesive coalition. The concept of "Minimal Range Coalitions" or "Minimal Connected Winning Coalitions" can be applied as well, by excluding the undisciplined members of coalition and giving more attention to the loyal parties.

b. Coalition Building in The Era of Jokowi-JK (2014-2019)

Coalition building in the era of President Joko Widodo and Vice-President Jusuf Kalla (Jokowi-JK) is empirically different with the coalition models in two prior periods. Although, there are some evidences which make it similar with the previous practices.

Legislative election in 2014 has resulted 10 (ten) political parties which have right to be seated in parliament. The composition of the members in parliament from each political partiy can be described in the following table. ${ }^{44}$

Table 1.

Result of Indonesia Legislative Election 2014

\begin{tabular}{clcc}
\hline No. & Political Parties & Chairs & $\begin{array}{c}\text { Percentage } \\
\mathbf{( \% )}\end{array}$ \\
\hline 1 & PDI-P & 109 & 19.46 \\
2 & Golkar Party & 91 & 16.25 \\
3 & Gerindra Party & 73 & 13.04 \\
4 & Democratic Party & 61 & 10.89 \\
5 & PAN & 48 & 8.57 \\
6 & PKB & 47 & 8.39 \\
7 & PKS & 40 & 7.14 \\
8 & PPP & 39 & 6.96 \\
9 & National Democratic & 36 & 6.43 \\
& Party & & \\
10 & Hanura & 16 & 2.86 \\
& Total Number & 560 & 100.0 \\
\hline
\end{tabular}

Source: Website Indonesian House of Representatives, 2014

The table shows that there is no-single party with majority status in parliament. Further, 10 (ten) political parties could also mean 10 (ten) or more political interests and policy preferences which can bring many considerations in building a variety form of coalitions.

In this era, there are only two grand coalitions: "Merah-Putih" Coalition (KMP) which was initially made by 6 (six) parties: 5 (five) in parliament and 1 (one) party outside the parliament i.e.: Gerindra, PAN, PPP, PKS, Golkar, and PBB. The Democrat, former presiding party in two previous cabinets, is taking position to be a balancing or neutral party in the parliament. Along with the political dynamics among the parties, PPP (at 
October 2014) and PAN (at September 2015) decided to secede from the KMP coalition. Both parties shifted their position to support the cabinet of Jokowi-JK and collaborating together with PDI-P in "Indonesia Hebat" Coalition (KIH) ${ }^{45}$

"Indonesia Hebat" Coalition (KIH) consists of PDI-P (as the leader of the grand coalition), PKB, Nasdem, Hanura, and PKPI (outside the parliament). This coalition was declared on 19 May 2014 at Djoeang Building, Jakarta. And as mentioned before, the dynamics of politics in Indonesia make PPP and PAN decide to retreat from the KMP coalition and officially declare to be part of the new member in KIH coalition. ${ }^{46}$

Before October 2014 and September 2015, "Indonesia Hebat" Coalition (KIH) only possessed 208 chairs in the parliament consisting of 109 for PDI-P, 36 for Nasdem, 47 for PKB, and 16 for Hanura. ${ }^{47}$ This was a minority coalition in parliament with all the facts that chairmans of parliament and MPR are controlled by KMP representatives. But in October 2014 and September 2015, $\mathrm{KIH}$ coalition was added by PPP and PAN. By joining the coalition, both parties have made KIH coalition to be the majority in parliament, by collecting 295 chairs. This turning situation left KMP with only 204 chairs in parliament and the rest is controlled by the Democrats with only 61 chairs as the balancing or neutral party. ${ }^{48}$

Considering the facts above, we can say that initially, PDI-P was focusing to initiate an effective and long-lived coalition even with only minority of members in parliament. But the important modalities in that coalition are the commitment and cohesiveness from each member. This fact shows that the commitment and discipline of KIH coalition are better than the KMP'.

Apart from the facts mentioned above, there are some factors causing the coalition in KMP was short-lived within less than 1 (one) year. These factors can be considered as indirect supports for $\mathrm{KIH}$ to gain and maintain its coalition stronger and more cohesive than the KMP. Those factors are as follows:

Firstly, internal conflict of two established political parties in KMP coalition, PPP and Golkar. It is even worst because both parties are now disintegrated into two managements. One of them has declared as the new PPP and Golkar party. The separation has also influenced members in parliament to turn their commitment from KMP coalition.

Secondly, informal and liquid political approach used by PDI-P and its coalition members in building a political relation with KMP coalition members and even with the Democrats is well-maintained.

Thirdly, Jokowi-JK does not focus in gathering many members to enter the coalition but effective partners to support the government. This option makes the cabinet giving more attentions to policy and program and then building images of the cabinet as hard workers and committing to the public. ${ }^{49}$

Fourthly, initial members of the coalition are cohesive and closely related to PDI-P as the leader and initiator of $\mathrm{KIH}$ coalition. It is different with the initial members in KMP. This factor may be one of the influential sides for other parties to turn their political position and be willing to be part of the coalition.

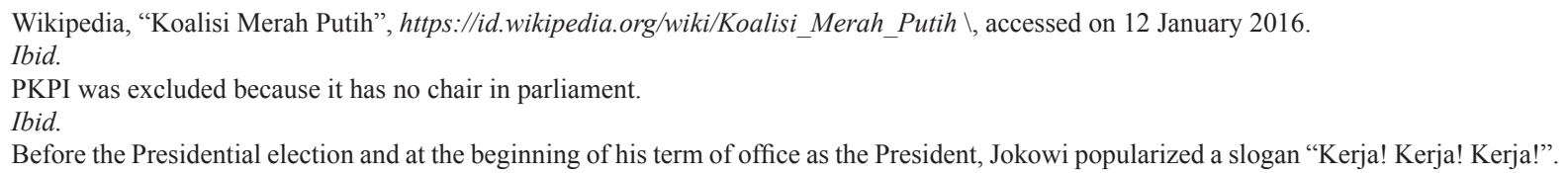


Lastly, classic political reason that political party always tends to maximize its power and existence by choosing to be partner of the cabinet. Coalition in presidential system would give more opportunities for members to be appointed as public officials or even a minister with high prestige and valuable experience. Moreover if the president and the cabinet are very popular and have high confidence in the eyes of public. This factor can be considered as the political externalities.

If we used the theory of coalitions from Lijphart's perspective, the coalition in the era of Jokowi-JK, actually, can be seen as one of the examples of "Minimal Range Coalitions" which is intended to get supports to form and maintain coalitions among parties with similar policy preferences than among parties that are far apart.

Further, PDI-P is trying to build more cohesive and stronger coalitions by applying such an idea of "Minimal Connected Winning Coalitions" ${ }^{\prime 50}$. This argumentation is based on the fact that when shaping KIH coalition, PDI-P did not give much attention to collect as many parties as possible to join the coalitions, though, PPP and PAN have finally chosen to change their political interest from KMP to KIH. In this context, PDI-P looks for connected parties to join in based on their political interest and policy preferences to support Jokowi-JK in the cabinet.

\section{Conclusion}

In a presidential system with multiparty design, coalition is an inevitable thing. Even when many empirical facts denote that coalition does not guarantee a stable and effective government, but in many moments, President will need coalitions to support his/her policy and program in parliament and in public.

In order to get around the effective coalition in a presidential system, President should not put his/her expectation only to the members of coalition, because empirically there is no relation between coalitions in parliament with the support in the cabinet. President also has to use his/her political and non-political modalities as a coalition builder to gain sympathy and positive image in parliament and in public. His/her informal and liquid approach can bring chances to open another relation with neutral or even opposite party.

Presidential coalition character is very different compared to parliamentary system. Coalition in a parliamentary design is more naturally and logically happened. Coalition model in presidential system is a pseudo-coalition because it does not always bring stability and cohesiveness within the coalition and cabinet, but long-lived conflicts and even delegitimacy for the President and cabinet in the eye of society.

From the empirical evidences of three era of cabinet, coalition should not only be based on the size of the members but also on the similarities of policy preferences, interests, political relations, and ideology. These factors will bring more stable, cohesive, and well-diciplined coalition in supporting the cabinet.

\section{REFERENCES}

\section{A. Books}

Apter, David E., 1977, Intoduction to Political Analysis, Winthrop Publishers Inc., Cambridge.
Asshiddiqie, Jimly, 2005, Implikasi Perubahan UUD 1945 Terhadap Pembangunan Hukum Nasional, MKRI, Jakarta.

Azari, Julia R., et al., 2013, The Presidential

\footnotetext{
50 The underlying assumption of this theory is that parties will try to coalesce with their immediate neighbors and that other adjacent parties will be added until a majority coalition is formed. See Arend Lijphart, 1999, Op.cit., pp. 99.
} 
Leadership Dilemma: Between the Constitution and a Political Party, Suny Press, New York.

Efriza, 2012, Political Explore: Sebuah Kajian Ilmu Politik, Alfabeta, Bandung.

Lijphart, Arend, 1984, Democracies: Pattern of Majoritarian and Consensus Government in Twenty-One Countries, Yale Universtity Press, New Haven. , 1999, Patterns of Democracy: Government Forms and Performance in Thirty-Six Countries, Yale University Press, New Heaven.

2002, Parliamentary Versus Presidential Government, Oxford University Press, New York.

Manan, Bagir, 1999, Lembaga Kepresidenan, Gama Media, Yogyakarta.

\section{B. Journal Articles}

Juan J. Linz, "The Perils of Presidentialism", Journal of Democracy, Vol. 1, No. 1, 1990.

Siska Yuspitasari, "Sistem Multipartai di Era Pemerintahan Susilo Bambang Yudhoyono 2004-2009”, Jurnal Dinamika Politik, Vol. 1, No. 1, August 2012.

\section{Paper/Speech}

Scott Mainwaring, "Presidentialism, Multiparty Systems, and Democracy: The Difficult Equation", Working Paper \#14, Kellogg Institute, September 1990.

\section{Internet Articles}

Cheibub, Jose A., "Systems of Government: Parliamentarism and Presidentialism",

http://www.hks.harvard.edu/fs/pnorris/Acrobat/ stm103\%20articles/Cheibub_Pres_Parlt.pdf , accessed 12 January 2016.

Cox, Gary W and Mccubbins, Matthew D, "The Institutional Determinants of Ecoomic Policy Outcomes", http://wcfia.harvard.edu/ files/wcfialfiles/671_mccubbins_cox.pdf , accessed 10 Januari 2016.

Wiki Summary, "President's sources of power (Richard Neustadt)", http://wikisum.com/w/ Neustadt:_Presidential_power, accessed 12 January 2016.

2002, "Minority Governments, Deadlock Situations, and the Survival of Presidential Democracies", http://cps. sagepub.com/cgi/content/abstract/35/3/284, accessed 29 October 2009.

Antara News, "38 Parpol Ditetapkan Menjadi Peserta Pemilu 2009", http://www.antara. co.id/view/? $i=1218891252 \& c=N A S \& s=$, accessed 24 Mei 2010.

Indonesian House of Representatives, "Fraksi", http://www.dpr.go.id/tentang/fraksi, accessed 12 January 2016.

Wikipedia, "Koalisi Merah Putih", https:// id.wikipedia.org/wiki/Koalisi_Merah_Putih I, accessed 12 January 2016. 